\title{
Identification of genes and pathways associated with aluminum stress and tolerance using transcriptome profiling of wheat near-isogenic lines Mario Houde* and Amadou Oury Diallo
}

Address: Centre TOXEN, Département des Sciences biologiques, Université du Québec à Montréal, C.P. 8888, Succ. Centre-ville, Montréal QC, H3C 3P8, Canada

Email: Mario Houde* - houde.mario@uqam.ca; Amadou Oury Diallo - diallo.amadou_oury.2@courrier.uqam.ca

* Corresponding author

Published: 27 August 2008

BMC Genomics 2008, 9:400
Received: 28 March 2008

Accepted: 27 August 2008

This article is available from: http://www.biomedcentral.com//47/-2164/9/400

(c) 2008 Houde and Diallo; licensee BioMed Central Ltd.

This is an Open Access article distributed under the terms of the Creative Commons Attribution License (http://creativecommons.org/licenses/by/2.0), which permits unrestricted use, distribution, and reproduction in any medium, provided the original work is properly cited.

\begin{abstract}
Background: Aluminum is considered the most limiting factor for plant productivity in acidic soils, which cover large areas of the world's potential arable lands. The inhibition of root growth is recognized as the primary effect of Al toxicity. To identify genes associated with Al stress and tolerance, transcriptome analyses of four different wheat lines ( $2 \mathrm{Al}$-tolerant and $2 \mathrm{Al}$ sensitive) that differ in their response to Al were performed.
\end{abstract}

Results: Microarray expression profiling revealed that 83 candidate genes are associated with $\mathrm{Al}$ stress and 25 are associated with tolerance. The stress-associated genes include important enzymes such as pyruvate dehydrogenase, alternative oxidase, and galactonolactone oxidase, $A B C$ transporter and ascorbate oxido-reducatase. The Al tolerance-associated genes include the ALMTI malate transporter, glutathione S-transferase, germin/oxalate oxidase, fructose 1,6bisphosphatase, cysteine-rich proteins, cytochrome $\mathrm{P} 450$ monooxygenase, cellulose synthase, zinc finger transcription factor, disease resistance response protein and F-box containing domain protein.

Conclusion: In this survey, we identified stress- and tolerance-associated genes that may be involved in the detoxification of $\mathrm{Al}$ and reactive oxygen species. Alternative pathways could help maintain the supply of important metabolites $\left(\mathrm{H}_{2} \mathrm{O}_{2}\right.$, ascorbate, $\mathrm{NADH}$, and phosphate) needed for $\mathrm{Al}$ tolerance and root growth. The $\mathrm{Al}$ tolerance-associated genes may be key factors that regulate these pathways.

\section{Background}

Aluminum is considered as the most limiting factor for plant productivity in acidic soils. It is estimated that over $50 \%$ of the world's potential arable land surface is composed of acid soils mostly distributed in developing countries $[1,2]$. Al tolerance is second to drought tolerance for its importance as agronomic trait for worldwide crop pro- duction. The root apex is considered the first target of $\mathrm{Al}$ toxicity and the reduction in root biomass leads to poor uptake of water and nutrients [3]. At the cellular level, Al toxicity results from a broad spectrum of deleterious effects caused by the $\mathrm{Al}^{3+}$ ion, which is considered the most toxic species of $\mathrm{Al}$ for both plant and animal cells under low $\mathrm{pH}$ conditions [4]. It was proposed that the 
toxic effect of $\mathrm{Al}$ can be reduced by chelating $\mathrm{Al}$ in the rhizosphere with organic anions. Exudation of a variety of organic anions such as malate, citrate, or oxalate upon exposure to $\mathrm{Al}$ have been reported $[2,5,6]$ and $\mathrm{Al}$ tolerance of several species can be enhanced by increasing organic acid biosynthesis [7-10]. Overexpression of the Al-inducible malate transporter improves Al tolerance in barley [11] while overexpression of the SbMATE protein, a putative citrate transporter, improves $\mathrm{Al}$ tolerance in Arabidopsis and wheat [12]. The release of phosphate was also associated with $\mathrm{Al}$ tolerance, indicating that multiple mechanisms are involved in wheat [13]. In Arabidopsis, the major Al tolerance quantitative trait loci (QTL) was proposed to be proximal to the AtALMT1 malate transporter and to involve additional genes [14]. Fine mapping indicated that Al tolerance is more closely associated with a chromosome location that is distal to AtALMT by 1400 to $2100 \mathrm{kbp}$ indicating that other gene products may regulate or complement its activity [14]. This regulation may be controlled at the transcriptional, translational, posttranslational and enzymatic levels. The association of organic acid release and $\mathrm{Al}$ tolerance is not universal as several Al-sensitive plants were found to secrete large amounts of organic acids $[15,16]$. These results suggest that organic acid excretion, per se, is not a tolerance (or resistance) mechanism, but a consequence of biochemical reactions required for $\mathrm{Al}$ tolerance. In Arabidopsis, there was no induction of AtALMT1 by $\mathrm{Al}^{3+}$ in the stop1 Arabidopsis mutant suggesting that the STOP1 zinc finger protein is required to activate ALMT1 transcription [17]. The $A L S 3$ gene encodes an $\mathrm{ABC}$ transporter-like protein that is required for $\mathrm{Al}$ tolerance/resistance and may function to redistribute accumulated $\mathrm{Al}$ away from sensitive tissues to protect growing roots from Al toxicity [4]. Several genes up-regulated during $\mathrm{Al}$ exposure have been identified using various molecular approaches [18-22]. Overexpression of some of these genes in transgenic plants has resulted in modest improvement of Al tolerance, suggesting that they alleviate part of the toxicity caused by $\mathrm{Al}$ [2327]. In rice, $\mathrm{Al}$ tolerance appears to be a complex multigenic trait that involves all twelve chromosomes. However, fewer loci were reported to be involved in other grasses $[2,28,29]$. Two major loci on chromosome $4 \mathrm{DL}$ and $6 \mathrm{~A}$, and additional loci with additive effects are involved in Al tolerance of the wheat cultivar Atlas 66 $[30,31]$. The availability of near-isogenic lines derived from the cultivar Atlas66 having similar QTLs for Al tolerance provides a useful tool to identify genes associated with $\mathrm{Al}$ stress and tolerance [30,31].

In this study, several genes associated with $\mathrm{Al}$ stress and tolerance were identified using transcriptome analyses. The putative functions of identified genes in several biochemical pathways are discussed in relation to stress responses and the maintenance of root growth.

\section{Results}

To identify genes associated with $\mathrm{Al}$ stress and tolerance in wheat, a large scale expression profiling study was initiated using the Affymetrix GeneChip ${ }^{\otimes}$ Wheat Genome Array which allows the screening of 55052 transcripts. To better discriminate between genes that are associated with $\mathrm{Al}$ stress and tolerance, four different wheat lines (two Altolerant and two Al-sensitive) were analyzed. In addition to the well studied tolerant wheat Atlas66 and the sensitive wheat Bounty used in our previous study [19], we used two near isogenic lines (NILs) derived from a cross between Atlas66 and the sensitive cultivar Century [32]. The sensitive NIL OK91G108 (named Century-S thereafter) has a high degree of genetic similarity (96.9\%) with the tolerant NIL OK91G106 (named Century-T thereafter). The major difference between tolerant and sensitive plants is the ability to maintain growth under high $\mathrm{Al}$ concentrations. The tolerant cultivars used in this study are able to grow for several days (50\% rate of control plants or a root growth inhibition $(\mathrm{RGI})=50 \%$ ) in the presence of $50 \mu \mathrm{M} \mathrm{Al}$ (result not shown). The sensitive cultivars are unable to grow at this high $\mathrm{Al}$ concentration and an RGI of $50 \%$ is obtained in the presence of $5 \mu \mathrm{M} \mathrm{Al}$. We have previously shown that the stress-associated genes are expressed at comparable levels in the sensitive and tolerant cultivars after 24 hours when they are exposed to $\mathrm{Al}$ concentrations resulting in a similar RGI [19]. The microarray experiments were thus designed to identify genes that are differentially expressed after 24 hours of Al exposure at concentrations resulting in 50\% RGI for all lines used.

\section{Microarray analyses}

The number of Al-regulated genes (differential expression between Al-treated and untreated plants) is over 1000 when cultivars are analyzed separately. However, only 263 genes are differentially expressed in all four cultivars. ANOVA analyses with stringent $\mathrm{p}$ values retained 83 of these genes as highly significantly regulated (Table 1 ; additional file 1). Among these genes, 20 were previously identified as up-regulated by $\mathrm{Al}$ (references in Table 1). We randomly selected 4 of the stress candidate genes for qRT-PCR validation (see bold probeset IDs in Table 1). Two of them (genes \# 2 and 3 ) are strongly over-expressed in response to $\mathrm{Al}$, one (gene \# 5, oxalate oxidase) was previously shown to be up-regulated by $\mathrm{Al}$ and the fourth one (gene \# 49) was represented by 5 different genes (genes \# $49,61,73,74$, and 76).

As found for stress-associated genes, microarray analyses allowed the identification of more than 1000 genes potentially associated with Al tolerance when selection was performed using only one pair of wheat lines (differential expression between Atlas66/Bounty or Century-T/ Century-S exposed to Al) but this number was reduced to 


\begin{tabular}{|c|c|c|c|c|}
\hline $\begin{array}{l}\text { Gene number/ } \\
\text { Response type }\end{array}$ & ProbesetIDs ${ }^{b}$ & Tentative annotationc & $\begin{array}{l}\text { Representative GenBank/ } \\
\text { Closest TIGR TC ID }\end{array}$ & $\begin{array}{l}\text { Reference/ } \\
\text { fold change }\end{array}$ \\
\hline I- Stress & Ta.25382.I.SI_at & Putative glutathione S-transferase & CD452690/TC271794 & {$[20] / 11.4$} \\
\hline 2- Pathogen & Ta.192.I.SI_at & $\mathrm{WCl}-5$ & $\underline{\mathrm{U} 32431.1 / T C 236905}$ & 8.4 \\
\hline 3- Unknown & Ta.I292I.I.SI_x_at & Similar to XP_4677II.I & $\overline{\mathrm{CA} 601406 / T C 239727}$ & 7.9 \\
\hline 4- Stress & Ta.5024.I.SI_x_at & Wali6 & L28009.I/TC2525I3 & {$[64] / 7.3$} \\
\hline 5- Stress & Ta.5557.I.SI_x_at & Putative germin/oxalate oxidase & CD869243/TC250530 & {$[19,65] / 7.0$} \\
\hline 6- Unknown & Ta.1267I.I.SI_a_at & Moderately similar to NP_909983.1 & CK194385/TC265258 & 6.3 \\
\hline 7- Unknown & Ta.8907.I.SI_at & Weakly similar to XP_48I678.I & 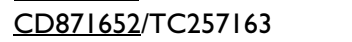 & 6.1 \\
\hline 8- Pathogen & Ta.|407I.2.SI_a_at & Putative nodulin MtN2I & CA642218/TC23647I & 6.0 \\
\hline 9- Unknown & Ta.I3875.I.SI_at & Putative cyclin-dependent kinase 5 activator 2 precursor & AL830660/TC254582 & 5.9 \\
\hline 10- Pathogen & Ta.23I.I.SI_x_at & Secretory protein (WAS-2) & AF079526.I/TC234692 & 5.8 \\
\hline II- Pathogen & Ta.2784.I.AI_at & Chi I mRNA for chitinase I & 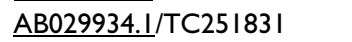 & 5.7 \\
\hline 12- Unknown & Ta.25I40.I.SI_at & Moderately similar to XP_477866.I integral membrane protein-like & $\overline{\mathrm{CD} 866293 / \mathrm{TC} 268024}$ & 5.6 \\
\hline 13- Stress & Ta.298I4.I.SI_at & Class III peroxidase 15 precursor & 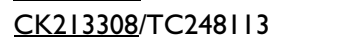 & {$[19] / 5.5$} \\
\hline 14- Signalling & Ta.II67I.I.SI_at & Putative heat shock transcription factor & 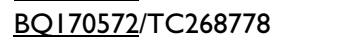 & 5.4 \\
\hline 15- Stress & Ta.21267.I.SI_s_at & Wali3 & $\overline{\mathrm{CA} 694095 / T C 250582}$ & {$[18] / 5.4$} \\
\hline 16- Unknown & TaAffx.7032.I.SI_at & Unknown & CA670339 & 5.4 \\
\hline 17- Unknown & Ta.I4I29.I.SI_at & Weakly similar to NP_181673.I proline-rich family protein & BQ789170/TC253690 & 5.3 \\
\hline 18- Stress & TaAffx.27822.I.SI_at & Wali5 & CA669899/TC234419 & {$[18] / 5.3$} \\
\hline 19- Stress & Ta.22673.I.SI_s_at & Germin GF-2.8 precursor; oxalate oxidase & $\mathrm{M} 21962 . \mathrm{I} / \mathrm{TC} 255645$ & {$[19] / 5.3$} \\
\hline 20- Metabolism & TaAffx.II8543.I.AI_at & Putative phragmoplastin (Oryza sativa) & $\overline{\mathrm{B} / 320269 / \mathrm{TC} 288239 \text { (rice) }}$ & 5.2 \\
\hline 21 - Stress & Ta.962.I.AI_at & Class III peroxidase I 5 precursor & $\mathrm{BQ} 160711 / \mathrm{TC} 247326$ & {$[19] / 5.2$} \\
\hline 22- Stress & Ta.2793.I.SI_at & Tamdr I mRNA; multidrug resistance protein I ( $A B C$ transporter) & $\mathrm{AB} 055077 . \mathrm{I} / \mathrm{TC} 275845$ & {$[21] / 5.1$} \\
\hline 23- Pathogen & Ta.23I.I.SI_at & Secretory protein (WAS-2) & AF079526.I/TC234692 & 5.1 \\
\hline 24- Stress & Ta.28233.I.SI_at & Putative iron/ascorbate-dependent oxidoreductase & CA599/87/TC246980 & 5.1 \\
\hline 25- Stress & Ta.18203.I.SI_at & Blue copper-binding protein & $\overline{\mathrm{AF} 031195.1 / T C 265708}$ & {$[20] / 5.0$} \\
\hline 26- Unknown & Ta.975.2.SI_at & Moderately similar to XP_475934.I & CK217120/TC246830 & 5.0 \\
\hline 27- Unknown & Ta.30765.I.SI_at & Weakly similar to XP_479604.I & CNOII347/TC257484 & 5.0 \\
\hline 28- Pathogen & Ta.8574.2.AI_at & Putative xylanase inhibitor TAXI-III & $\mathrm{BQ} 162077 / \mathrm{TC} 249173$ & 4.8 \\
\hline 29- Stress & Ta.24553.I.AI_at & Oxalate oxidase precursor (OXOI gene) & CA662341/TC264833 & {$[19] / 4.7$} \\
\hline 30- Stress & Ta.II025.I.AI_at & $\begin{array}{l}\text { FAD-binding domain-containing protein; putative arabinono-lactone oxidase (D- } \\
\text { erythroascorbate) }\end{array}$ & $\mathrm{BQ} 168402 / \mathrm{TC} 235458$ & 4.7 \\
\hline 31- Unknown & Ta.5824.I.SI_s_at & Moderately similar to XP_4677II.I & CA693256/TC263060 & 4.7 \\
\hline 32- Metabolism & Ta.653.I.SI_at & Putative xyloglucan endo-I,4-beta-D-glucanase & CK196945/TC253973 & {$[66] / 4.6$} \\
\hline 33- Unknown & TaAffx.42638.I.SI_at & Unknown & $\mathrm{BQ} 802968 / \mathrm{TC} 253690$ & 4.5 \\
\hline 34- Pathogen/signalling & Ta.4479.I.SI_at & Putative disease resistance protein; leucine-rich repeat family protein & CNOII595/TC262862 & 4.4 \\
\hline 35- Stress & Ta.21350.I.SI_x_at & Wali5 & LII $882.1 / T C 234419$ & {$[18] / 4.4$} \\
\hline 36- Stress & Ta.27945.I.SI_x_at & $\begin{array}{l}\text { ABA responsive protein; putative glucosyltransferases } \\
\text { (pfam domain) (cell wall metabolism) }\end{array}$ & CK216098/TC248224 & 4.3 \\
\hline 37- Pathogen/signalling & Ta.4479.2.SI_a_at & Putative disease resistance protein; leucine-rich repeat family protein/putative protein kinase & CA735391/TC262862 & 4.3 \\
\hline 38- Unknown & Ta.I5I99.I.SI_at & Weakly similar to NP_9| I238.I & CA65305I/TC260490 & 4.3 \\
\hline 39- Stress & Ta.307II.I.SI_x_at & Wali5; putative proteinase inhibitor (wrsi5-I) & AY549888. I/TC234467 & {$[18] / 4.3$} \\
\hline 40- Signalling & Ta.30908.I.SI_at & Putative EF-hand $\mathrm{Ca}$ 2+-binding protein $\mathrm{CCDI}$ & CN013064/TC254944 & 3.9 \\
\hline 4I- Signalling & Ta.I9062.I.SI_at & Putative EF-hand $\mathrm{Ca} 2+-$ binding protein $\mathrm{CCDI}$ & CA646724/TC254944 & 3.8 \\
\hline 42- Pathogen & TaAffx.|5836.I.SI_at & Harpin induced protein pfam domain, hypersensitive response & $\overline{\mathrm{BO} 803322} / \mathrm{TC} 300996$ (rice) & 3.7 \\
\hline 43- Signalling & TaAffx.II075I.I.SI_s_at & Putative EF-hand Ca2+-binding protein CCDI & 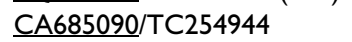 & 3.7 \\
\hline
\end{tabular}


Table I: Aluminum stress-regulated genes from wheat identified by microarray profiling (Continued)

\begin{tabular}{|c|c|c|c|c|}
\hline 44- Stress & Ta.6797.I.Al_at & Putative S-adenosylmethionine decarboxylase 2 & $\mathrm{~B}, 3 / 1 / 153 / \mathrm{TC} 261365$ & 3.7 \\
\hline 45- Stress & Ta.I05.I.SI_at & Wali3 & LIII88I.I/TC268347 & {$[18] / 3.6$} \\
\hline 46- Metabolism & Ta.4199.I.SI_a_at & Putative arabinoxylan arabinofuranohydrolase & CK199568/TC23474I & 3.5 \\
\hline 47- Unknown & Ta.4343.I.SI_x_at & Weakly similar to NP_196028.2 & 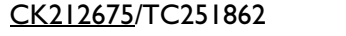 & 3.5 \\
\hline 48- Unknown & Ta.30942.I.SI_a_at & Unknown & BE515762/TC255I8I & 3.4 \\
\hline 49- Pathogen & Ta.392.2.SI_at & B2 protein; DCD (development and cell death) Interpro domain IPR0I3989 & CA659319/TC23464I & 3.4 \\
\hline 50- Signalling & TaAffx.I2862I.I.SI_at & Putative EF-hand Ca2+-binding protein; calmodulin-like & CK200510/TC269114 & 3.4 \\
\hline 5I-Metabolism & Ta.6099.I.SI_at & Nitropropane dioxygenase-like (pfam domain) & CA667895/TC235667 & 3.4 \\
\hline 52- Pathogen & Ta.I370I.I.SI_at & $\begin{array}{l}\text { Benzoyl coenzyme A: benzyl alcohol benzoyl transferase; Putative hypersensitivity-related } \\
\text { (hsr)protein }\end{array}$ & $\underline{\mathrm{BQ} 280458 / T C 270357}$ & 3.4 \\
\hline 53- Unknown & TaAffx.10772.I.AI_at & Unknown & CK213044/TC24II 05 & 3.4 \\
\hline 54- Signalling & Ta.I5067.I.SI_at & Putative EF-hand Ca2+-binding protein CCDI & CD876309/TC260557 & 3.4 \\
\hline 55- Signalling & Ta.I5067.I.SI_x_at & Putative EF-hand Ca2+-binding protein CCDI & CD876309/TC260557 & 3.4 \\
\hline 56- Unknown & Ta.24654.I.SI_at & Unknown & CA605778/TC252436 & 3.4 \\
\hline 57- Unknown & Ta.I422I.I.SI_s_at & Weakly similar to XP_470656.I & BO838103/TC258780 & 3.3 \\
\hline 58- Unknown & Ta.2I307.I.SI_x_at & Putative peroxidase & CK199589/TC249039 & {$[19] / 3.3$} \\
\hline 59- Unknown & TaAffx.22704.I.SI_at & Putative GABA-specific permease & CA746306/TC3I4548 (rice) & 3.2 \\
\hline 60- Signalling & Ta.89|4.I.SI_at & Putative serine/threonine protein kinase & BQ162624/TC248336 & 3.2 \\
\hline 61- Pathogen & Ta.392.2.SI_x_at & B2 protein; DCD (development and cell death) Interpro domain IPR0I3989 & 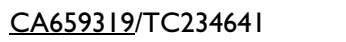 & 3.1 \\
\hline 62- Metabolism & Ta.2II66.I.SI_at & Putative shikimate kinase chloroplast precursor & CD492089/TC236265 & 3.1 \\
\hline 63- Signalling & TaAffx.10874.I.SI_at & Putative Receptor protein kinase-like protein & 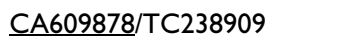 & 3.1 \\
\hline 64- Unknown & TaAffx.28I56.I.SI_at & Unknown & 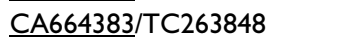 & 3.1 \\
\hline 65- Metabolism & Ta.2995I.I.SI_at & Putative pyruvate dehydrogenase EI alpha subunit, mitochondrial & $\overline{\mathrm{CD} 903633 / T C 249785}$ & 3.0 \\
\hline 66- Signalling & TaAffx.II075I.I.SI_x_at & Putative EF-hand Ca2+-binding protein CCDI & CA685090/TC254944 & 3.0 \\
\hline 67- Unknown & TaAffx.10772.I.AI_s_at & Unknown & CK213044/TC24II05 & 2.9 \\
\hline 68- Unknown & Ta.9255.I.SI_at & Weakly similar to NP_523812.1; Leucine-rich protein & $\overline{\mathrm{CK} 208205 / T C 265940}$ & 2.9 \\
\hline 69- Unknown & Ta.I2565.3.SI_a_at & Putative ubiquitin-associated (UBA) protein & CA705730/TC247679 & 2.8 \\
\hline 70- Stress & Ta.24I50.I.SI_at & Glutathione-S-transferase 19E50 & AY064481.I/TC266491 & {$[20] / 2.8$} \\
\hline 7I- Pathogen & Ta.I3785.I.SI_at & Xylanase Inhibitor Protein (Xip-I) & 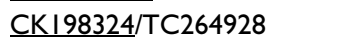 & 2.7 \\
\hline 72- Metabolism & Ta.I0549.I.AI_x_at & Alternative oxidase 3 & CA609877/TC26760I & {$[67] / 2.7$} \\
\hline 73- Pathogen & Ta.392.I.SI_at & B2 protein; DCD (development and cell death) Interpro domain IPR0I3989 & CK200130/TC23464I & 2.7 \\
\hline 74- Pathogen & Ta.392.3.AI_s_at & B2 protein; DCD (development and cell death) Interpro domain IPR0I3989 & $\underline{\mathrm{CK} 164089 / T C 234641}$ & 2.7 \\
\hline 75- Unknown & Ta.4674.I.SI_s_at & Unknown & B]269896/TC243760 & 2.6 \\
\hline 76- Pathogen & Ta.392.I.SI_X_at & B2 protein; DCD (development and cell death) Interpro domain IPR0I3989 & CK200130/TC23464I & 2.6 \\
\hline 77- Metabolism & Ta.4I99.2.SI_at & Putative arabinoxylan arabinofuranohydrolase & CA60I65I/TC23474I & 2.6 \\
\hline 78- Unknown & Ta.28879.I.SI_at & Protein phosphatase type $2 \mathrm{C}$ & B]306387/TC263663 & 2.5 \\
\hline 79- Unknown & Ta.28879.2.SI_x_at & Protein phosphatase type $2 \mathrm{C}$ & CA744010/TC263663 & 2.4 \\
\hline 80- Unknown & Ta.255I4.I.SI_s_at & Polygalacturonase activity (GO:0004650) & 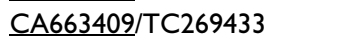 & 2.3 \\
\hline 8I- Unknown & Ta.12879.I.SI_at & Moderately similar to XP_463452.I & $\overline{\mathrm{CD} 490901 / T C 241688}$ & 0.3 \\
\hline 82- Pathogen & Ta.7963.2.SI_x_at & Putative disease resistance response protein & $\overline{\mathrm{CK} 215257 / T C 251022}$ & 0.2 \\
\hline 83- Stress & Ta.22968.I.SI_at & Putative lipid transfer protein & CA6145/9/TC247557 & {$[67] / 0.2$} \\
\hline
\end{tabular}

a: The response type is based on previous publications.

b: According to Affymetrix Gene Chip ${ }^{\circledR}$ wheat genome array description. The probesetIDs are presented in decreasing order of differential expression (most over-expressed to most downregulated). The last 3 entries are down-regulated genes. For more details on gene expression level, see Additional file I. Genes subsequently tested by qRT PCR are in bold. c: Annotations were made based on Affymetrix gene annotation complemented with BLAST results using the public representative ID provided with the Affymetrix Gene Chip ${ }^{\circledR}$ wheat genome array.

d: The fold change represents the mean ratio of gene expression in all cultivars exposed to $\mathrm{Al}(50 \% \mathrm{RGl}) /$ the controls not treated with $\mathrm{Al}$. 
69 common genes when both pairs were considered. This result suggests that a large number of genes are associated with cultivar specific responses and only a limited number of them are associated with $\mathrm{Al}$ tolerance. This list was reduced to 25 genes using ANOVA analyses with stringent p values (Table 2; additional file 2 ). These genes were subdivided into constitutively or differentially expressed genes based on the difference in expression between Altreated and non-treated control plants. Table $2 \mathrm{~A}$ lists the 6 constitutively expressed genes classified in decreasing order of expression (average fold expression of the two tolerant compared to the two sensitive cultivars). The most strongly expressed gene is the previously identified Al malate transporter ALMT-1 [33]. We selected two of these genes for qRT-PCR validation (gene \# 84 encodes ALMT-1 and is more expressed in tolerant cultivars while gene \# 89 encodes a protein containing an F-box domain and is more expressed in sensitive cultivars; Table 2A). Table $2 \mathrm{~B}$ lists the 19 genes that are regulated by $\mathrm{Al}$ and differentially expressed between the two tolerant and the two sensitive cultivars. Four of these genes were selected for validation by qRT-PCR (see bold probeset IDs in Table 2B).

\section{Quantitative RT-PCR validation of microarray data}

We selected ten genes for validation of the microarray data by qRT-PCR ( 4 among the stress-associated candidates and 6 among the tolerance-associated candidates, as indicated above). Four different $\mathrm{Al}$ concentrations (0, 5, 50 and $250 \mu \mathrm{M} \mathrm{Al}$ ) were used to determine the effect on gene expression. Four new replicates of each Al exposure conditions using all wheat lines were prepared. The values indicated in each histogram column represent the expression levels relative to the first column (cultivar Atlas66 not exposed to Al) (Fig. 1A-J). The level of expression of the tested genes under control conditions is generally similar in the tolerant and sensitive cultivars.

Genes were classified as associated with Al tolerance when there was a significant difference in expression in both tolerant cultivars (Atlas66 and Century-T exposed to $50 \mu \mathrm{M}$ $\mathrm{Al})$ compared to their respective sensitive counterparts (Bounty and Century-S exposed to $5 \mu \mathrm{M} \mathrm{Al}$ ). These conditions allow the detection of either 1) Al-regulated genes that may be expressed differentially in tolerant and sensitive lines, or 2) genes not regulated by $\mathrm{Al}$ (constitutively expressed) but showing constitutive difference in expression between tolerant and sensitive lines. Once classified as associated with stress or tolerance, gene regulation by $\mathrm{Al}$ was confirmed by comparing the Al-treated and nontreated controls. qRT-PCR, analyses confirmed that three (Ta.192.1.S1_at, Ta.12921.1.S1_x_at and Ta.392.2.S1_at, Fig. 1A-C) of the four stress candidate genes are stressassociated while the $4^{\text {th }}$ gene (Ta.5557.1.S1_x_at, Fig. 1D) is more closely associated with $\mathrm{Al}$ tolerance. Among the six selected tolerance candidates genes, four were confirmed as associated with $\mathrm{Al}$ tolerance (Fig. 1E-H: Ta.30659.1.S1_at,

TaAffx.16664.1.A1_at, Ta23271.1.S1_s_at, Ta.8545.1.S1_x_at) while the last two genes (Ta.21314.1.S1_x_at and Ta.24632.1.S1_at, Fig. 1I$\mathrm{J})$, were not clearly linked to either stress or tolerance.

The correlation between gene expression data obtained by microarray and qRT-PCR is presented in Fig. 2. Al-regulated genes are shown in Fig. 2A for the cultivars Atlas66 and Bounty. The fold change in gene expression (Altreated VS control) obtained using microarray experiments compared to the fold change obtained using qRTPCR gives a correlation coefficient of 0.61. A similar analysis was performed to compare the change in gene expression between the tolerant and sensitive cultivars (Atlas66 $50 \mu \mathrm{M} \mathrm{Al}$ /Bounty $5 \mu \mathrm{M} \mathrm{Al}$ and Century-T $50 \mu \mathrm{M} \mathrm{Al} /$ Century-S $5 \mu \mathrm{M} \mathrm{Al}$ ) calculated from the microarray or qRTPCR data (Fig. 2B). In this case, a correlation coefficient of 0.77 was obtained between the two experimental methods. These correlation coefficients are very good considering that microarray data are semi-quantitative and subject to error for multigene families where different transcripts could hybridize to similar probes on the array. qRT-PCR data are more specific since the amplification of single transcripts are confirmed by melting curves and gel analyses. The Ta.5557.1.S1_x_at was initially selected as a stress-associated gene by microarray profiling (gene no 5 in Table 1) while it was reclassified as associated with $\mathrm{Al}$ tolerance using qRT-PCR (Fig. 1D). This may be related to the presence of multiple oxalate oxidase genes in wheat. Based on these results, we conclude that most of the genes identified in Table 1 and Table 2 are associated with $\mathrm{Al}$ stress and tolerance. However, real-time PCR analyses will be required to validate the other genes that were identified using microarrays.

\section{Discussion}

Several Al-associated QTLs with major and minor contributions were reported, indicating that $\mathrm{Al}$ tolerance is a multigenic trait. A large scale transcriptome analysis was initiated to identify some gene components of this multigenic trait. The genes that are differentially expressed between tolerant and sensitive cultivars are of particular interest since the tolerant cultivars are exposed to $\mathrm{Al}$ concentrations that are ten times higher, yet they are still growing at the same rate as the sensitive cultivars. This design allows the distinction of genes that are regulated in response to stress from those that are associated with $\mathrm{Al}$ tolerance. Transcriptome analyses allowed the identification of several genes with known function that could improve our understanding of the biochemical processes and pathways involved in $\mathrm{Al}$ stress and tolerance. As indicated in the result section, 20 of the 83 genes associated with the Al stress response were identified in previous 
Table 2: Genes associated with Al tolerance in wheat, as identified by microarray profiling

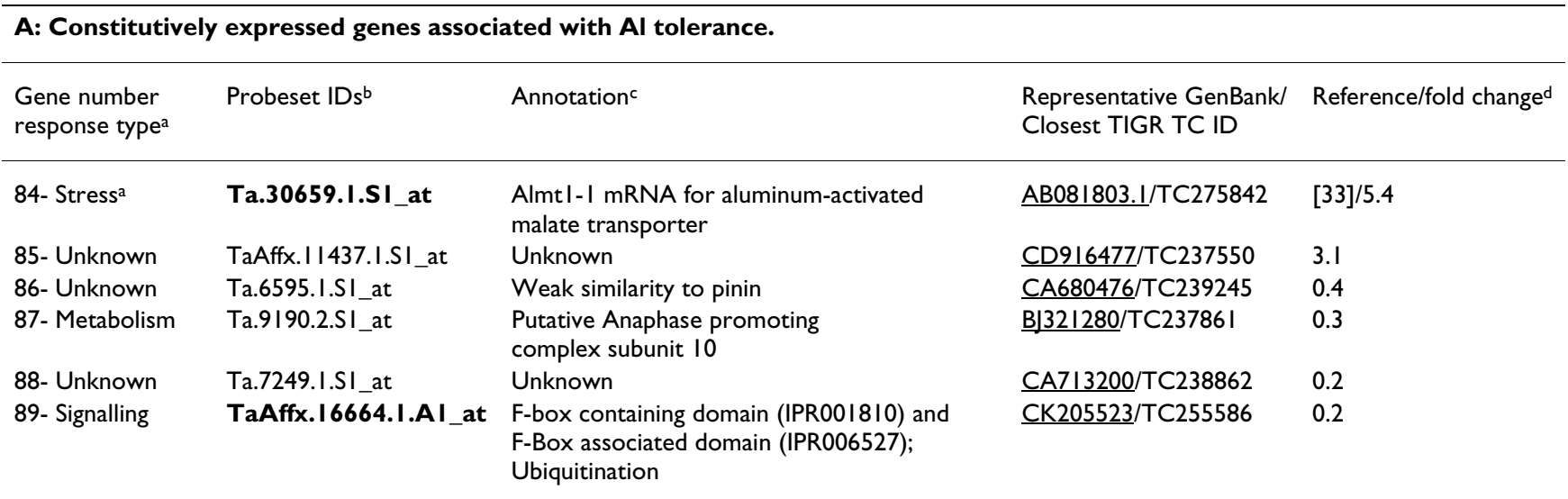

\section{B: Up-regulated genes associated with Al tolerance.}

\begin{tabular}{|c|c|c|c|c|}
\hline Response & Probeset IDs ${ }^{\mathrm{a}}$ & Annotation ${ }^{\mathrm{a}}$ & $\begin{array}{l}\text { Representative GenBank/ } \\
\text { Closest TIGR TC ID }\end{array}$ & $\begin{array}{l}\text { Reference/fold } \\
\text { change }^{d}\end{array}$ \\
\hline 90- Unknown & Ta.2327I.I.SI_s_at & unknown & CA680274/TC249675 & 7.6 \\
\hline 91 - Stress & Ta.8545.I.SI_at & Glutathione S-transferase (GST) & $\mathrm{BQ} 16204 \mathrm{I} / \mathrm{TC} 259746$ & 5.7 \\
\hline 92- Pathogen & Ta.2I3|4.I.SI_x_at & Similar to disease resistance response protein & CA669694/TC266782 & 5.2 \\
\hline 93- Unknown & TaAffx.26343.I.SI_at & Unknown & 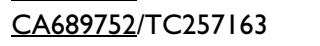 & 4.9 \\
\hline 94- Metabolism & Ta.8447.I.SI_a_at & Putative cytochrome P450 monooxygenase & CA669038/TC236876 & {$[67] / 4$} \\
\hline 95- Pathogen & Ta.24632.I.SI_at & $\begin{array}{l}\text { Pathogen response serine-type endopeptidase } \\
\text { inhibitor activity; putative protease inhibitor }\end{array}$ & BE405372/TC248320 & 4 \\
\hline 96- Stress & Ta.3II8.I.SI_at & Glutathione S-transferase & BE515437/TC238392 & 3.2 \\
\hline 97- Unknown & TaAffx.863I7.I.SI_at & $\begin{array}{l}\text { Yippee-like protein IPR004910; role in } \\
\text { cell division }\end{array}$ & CA611222/TC268232 & 3.2 \\
\hline 98- Pathogen & Ta.24632.I.SI_x_at & $\begin{array}{l}\text { Pathogen response serine-type endopeptidase } \\
\text { inhibitor activity; putative protease inhibitor }\end{array}$ & BE405372/TC248320 & 3.1 \\
\hline 99- Unknown & Ta.10326.I.SI_at & Unknown & B]244180/TC238059 & 3.1 \\
\hline I00- Unknown & Ta.14224.I.SI_at & $\begin{array}{l}\text { Weak similarity to Protamine IB or } \\
\text { Zinc Knuckle domain }\end{array}$ & CK214385/TC252792 & 3.1 \\
\hline I0I-Metabolism & Ta.28890.I.AI_s_at & $\begin{array}{l}\text { Fructose-1,6-bisphosphatase isozyme } 2 \\
(\mathrm{FI}, 6-\mathrm{BP})\end{array}$ & CA686703/TC23527I & 2.9 \\
\hline 102- Pathogen & Ta.24632.I.SI_a_at & $\begin{array}{l}\text { Pathogen response serine-type endopeptidase } \\
\text { inhibitor activity; putative protease inhibitor }\end{array}$ & BE405372/TC248320 & 2.9 \\
\hline I03- Unknown & Ta.13302.I.SI_at & Unknown & BQ80I428/TC258348 & 2.5 \\
\hline I04- Unknown & Ta.23097.I.SI_x_at & $\begin{array}{l}\text { Weak similarity to Adhesive/ } \\
\text { proline-rich-like protein }\end{array}$ & 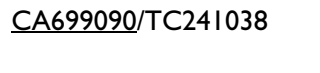 & 2.4 \\
\hline 105- Unknown & Ta.2976I.I.AI_at & Similar to At $2 \mathrm{~g} 31940$ & A] $609795 / T C 243334$ & 2.4 \\
\hline 106- Metabolism & Ta.4084.I.SI_at & $\begin{array}{l}\text { Putative cellulose synthase-like protein } \\
\text { OsCsIEI (cell wall metabolism) }\end{array}$ & B]264002/TC25382I & 2.4 \\
\hline 107- Signalling & TaAffx.|2876.I.SI_at & $\begin{array}{l}\text { Putative } \mathrm{C} 2 \mathrm{H} 2 \text { type zinc finger } \\
\text { transcription factor }\end{array}$ & B]220837/TC275754 & 2.1 \\
\hline 108- Pathogen & Ta.7883.I.SI_x_at & Putative disease resistance response protein & CK212322/TC267223 & 0.2 \\
\hline
\end{tabular}

a: The gene are numbered consecutively to Table I to simplify presentation in the text and Figure 3. The response type is based on previous publications.

b: According to Affymetrix Gene Chip ${ }^{\circledR}$ wheat genome array description. The probesetIDs are presented in decreasing order of differential expression (most over-expressed to most down-regulated). The last 4 entries in Table 2A are more expressed in sensitive cultivars. The last entry in Table 2B is a down-regulated gene in the tolerant cultivars. For more details on gene expression level, see Additional file 2 . Genes subsequently tested by $\mathrm{QRT}$ PCR are in bold.

c: Annotations were made based on Affymetrix gene annotation complemented with BLAST results using the public representative ID provided with the Affymetrix Gene Chip ${ }^{\circledR}$ wheat genome array.

$\mathrm{d}$ : The fold change represents the mean ratio of gene expression in the two tolerant cultivar/the two sensitive cultivar (50\% RGI). 


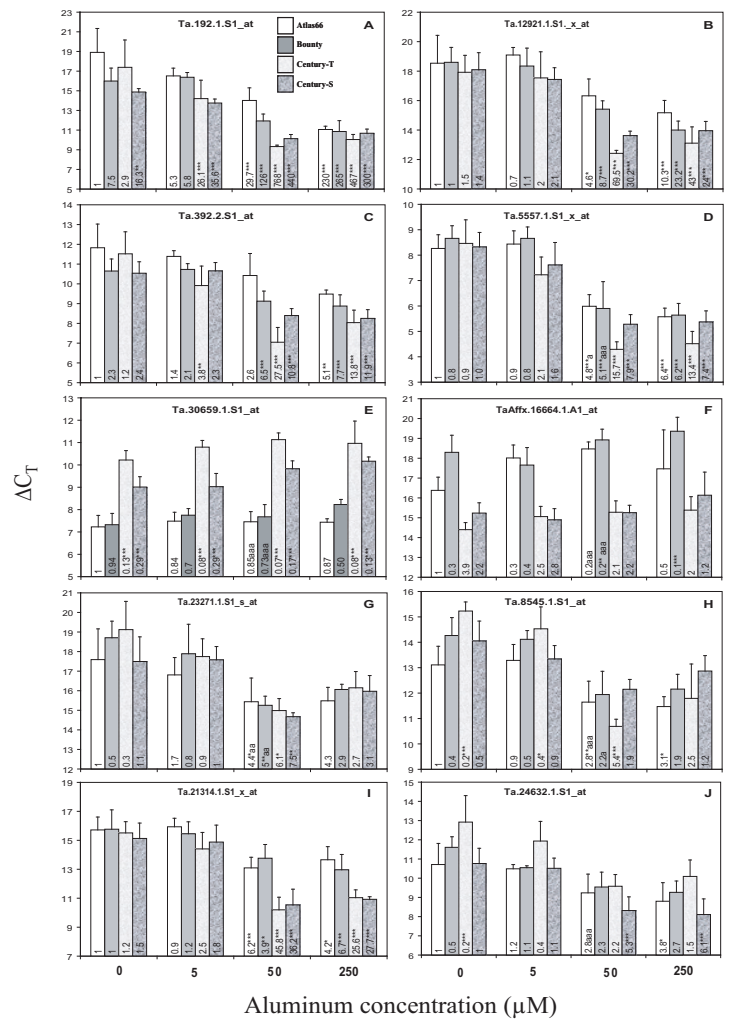

Figure I

Quantitative Real-Time PCR analysis of candidate genes. Control non-treated plants were exposed to a solution of I $\mathrm{mM} \mathrm{CaCl}_{2}, \mathrm{pH} 4$.I 5 for 24 hours while $\mathrm{Al}$ treatment was performed in the same solution containing 5, 50 or 250 $\mu \mathrm{M}$ Al. qRT-PCR was performed on four biological replicates. RNA was extracted, reverse-transcribed and the expression of genes identified in Tables I and 2 was measured using $\mathrm{QRT}-\mathrm{PCR}$. The $\mathrm{C}_{\mathrm{T}}$ values were normalized using the I8S RNA (note that a lower $\mathrm{C}_{T}$ means increased expression and $\mathrm{C}_{\mathrm{T}}$ difference of I represents a two-fold difference in expression). A statistical difference between each sample and the expression observed in Atlas66 not exposed to $\mathrm{Al}$ is indicated by an asterisk in the histogram columns (*: $p<.05$; **: $\mathrm{p}<.01$; ***: $\mathrm{p}<.00 \mathrm{I})$. A statistical difference between tolerant cultivars exposed to $50 \mu \mathrm{M} \mathrm{Al}$ and their sensitive counterpart exposed to $5 \mu \mathrm{M} \mathrm{Al}$ is indicated by an "a" after the asterisks (a: $\mathrm{p}<.05$; aa: $\mathrm{p}<.0 \mathrm{I}$; aaa: $\mathrm{p}<.00 \mathrm{I}$ ).

studies indicating that the genes associated with Al stress are appropriately identified using this approach.

\section{Signal transduction}

We have previously shown that $\mathrm{Al}$ inhibits a redox reaction associated with root growth and Al tolerance [34]. The perturbation of this redox reaction by $\mathrm{Al}$ could lead to

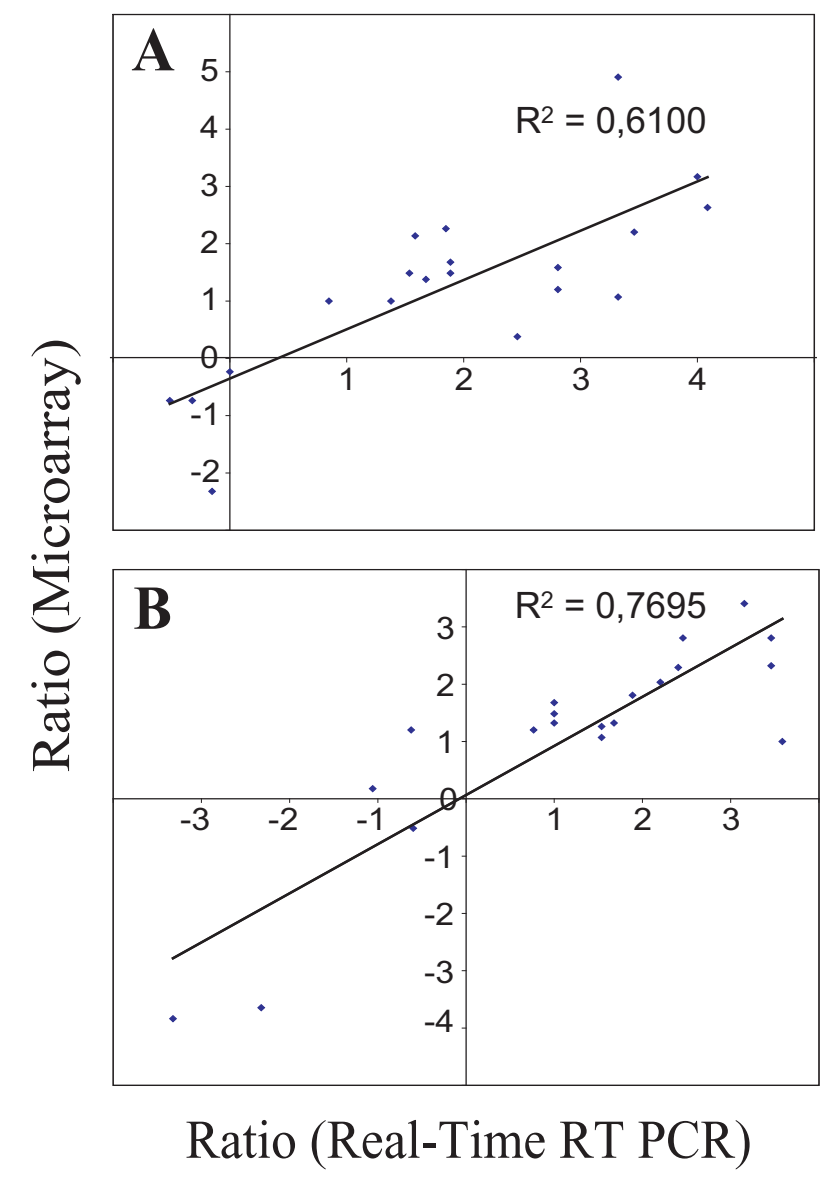

Figure 2

Correlation of qRT-PCR and microarrray data. A The ratio of gene expression ( $\log _{2}$ scale) in plants treated with $\mathrm{Al}$ and the control (not treated with $\mathrm{Al}$ ) was calculated in the microarray experiments and plotted against the ratio calculated in the qRT-PCR analyses. B - The ratio of gene expression ( $\log _{2}$ scale) in tolerant and sensitive cultivars exposed to Al giving the same RGI (Atlas66/Bounty or Century-T/Century-S) was calculated in the microarray experiments and plotted against the ratio calculated in the $\mathrm{qRT}$ $\mathrm{PCR}$ analyses.

the accumulation of different reactive oxygen species which can stimulate a redox signalling pathway and increase the expression of antioxidant enzymes [35]. The accumulation of reactive oxygen species during $\mathrm{Al}$ exposure was observed in maize, soybean and wheat [36-38]. Al was also shown to affect mitochondrial functions leading to ROS production [39]. Table 1 shows that the genes encoding WCI-5 (gene \# 2), WAS-2 (genes \# 10 and 23) and the EF-hand $\mathrm{Ca}^{2+}$-binding protein (genes \# 40, 41, 43, 54 and 55) are up-regulated during $\mathrm{Al}$ exposure. In Arabidopsis, the WCI-5 and WAS-2 genes were shown to be induced via a MAP kinase pathway associated with the pathogen response [40]. In wheat seedlings, the WCI-5 
gene was shown to be induced by pathogen infection [41] and mediated by the EF-hand $\mathrm{Ca}^{2+-}$-binding protein CCD1 [42]. These results suggest that a MAP kinase pathway is stimulated by $\mathrm{Al}$ in wheat roots as observed in cell suspension cultures of Coffea arabica L. [43]. Three different protein kinase-like genes (genes \# 37, 60, 63) are upregulated during $\mathrm{Al}$ exposure suggesting that different signal transduction pathways may be activated. We identified two other potential signalling genes associated with $\mathrm{Al}$ tolerance. The first one encodes a putative $\mathrm{C} 2 \mathrm{H} 2$ zinc finger transcription factor (gene \# 107) that has a 33 aa region sharing 50\% identity with the STOP1 C2H2 zinc finger protein required for $\mathrm{Al}^{3+}$ induction of $A L M T 1$ in Arabidopsis [17]. The other gene encodes an F-box containing protein (gene \# 89), which is member of a family known for its involvement in the controlled degradation of target proteins. An Arabidopsis F-box protein homologous to a bacterial redox sensor was proposed to be involved in the cell wall receptor-like associated kinase (WAK1) signalling pathway [44]. Since WAK1 was shown to be transiently overexpressed during $\mathrm{Al}$ exposure and associated with $\mathrm{Al}$ tolerance [27], the reduced expression of an F-Box protein may stimulate this pathway by allowing a stronger expression of WAK1 in tolerant cultivars. The TIR1 gene is another F-Box protein in Arabidopsis that interacts with different proteins in the SCFIIR1 complex to mediate responses to auxin $[45,46]$. These two genes (C2H2 zinc finger and F-Box) require further characterization and functional analysis to understand their roles in the response to $\mathrm{Al}$.

\section{Management of Al-associated stresses and maintenance of energy supply}

The identification of stress-regulated genes provide new tools to reduce $\mathrm{Al}$ stress, as shown by the ectopic overexpression of some Al stress-regulated genes [23-26]. Among the 83 candidate genes regulated by $\mathrm{Al}$ stress (Table 1), several could play a role in alleviating phosphate deficiency and provide energy to fight oxidative stress. Nutrient deficiency, and especially phosphate, occurs in the presence of $\mathrm{Al}$ due to the precipitation of $\mathrm{Al}$ phosphate [47]. Under phosphate deficiency, several pathways are hindered due to the reduced availability of ATP and related nucleoside phosphates. These imbalances lead to the induction of alternative pathways of glycolysis to maintain energy and carbon skeletons for key metabolic processes [48]. The fructose-1,6-bisphosphatase (gene \# 101) associated with Al tolerance (Table 2) is normally inhibited by phosphate but is stimulated under low phosphate availability (Fig. 3, Box 3). This activity produces fructose-6-P and liberates Pi. The glycolytic alternative enzyme pyrophosphate phosphofructokinase is stimulated by low phosphate and can resynthesise fructose-1,6-bisphosphate and liberate more Pi. This apparently futile cycle is useful to conserve ATP and recycle Pi that is readily available in the pyrophosphate molecule
[48]. Furthermore, since sucrose is the most abundant photosynthate available in the phloem sap, fructose (from sucrose) is readily available and will enter the glycolytic pathway at the level of fructose-6-P thereby maintaining a stable supply of this metabolite. The high availability of fructose-6-P (and other hexose-P) can provide sufficient metabolites to support both the pentose phosphate pathway and organic acid synthesis (Fig. 3, Box 3 ). Al-tolerant rye was found to maintain a higher content of glucose-6-phosphate than Al-sensitive wheat in response to $\mathrm{Al}$ exposure [49]. This metabolite is an important precursor of the pentose phosphate pathway (with glucose-6-phosphate dehydrogenase (G6PDH) as the first enzyme) and is an important source of NADPH production. The importance of energy metabolism in modulating $\mathrm{Al}$ tolerance is exemplified in Pseudomonas fluorescens where G6PDH was shown to play a pivotal role in enhancing NADPH production and protecting against ROS toxicity [50]. The up-regulation of pyruvate dehydrogenase (gene \# 65) and alternative oxidase (gene \# 72) supports the involvement of an alternative pathway to maintain energy production (Fig. 3, Box 3) [48]. Members of the alternative oxidase gene family were found to be highly responsive to oxidative stress and to reduce mitochondrial ROS production while maintaining NADH supply [51,52]. In Al tolerant plants, a higher NADH supply (and NADPH through the pentose phosphate pathway) would provide reducing power to regenerate ascorbate and glutathione to fight oxidative stress (Fig. 3, Box 3).

Exudation of organic acids has received much attention as an $\mathrm{Al}$ tolerance (resistance) mechanism. The secretion of malate or other organic acids (citrate, oxalate) can chelate $\mathrm{Al}$ in the rhizosphere and has been associated with $\mathrm{Al}$ tolerance in several species [7-10,33]. Enzymes involved in malate synthesis (PEP carboxylase and malate dehydrogenase, Fig. 3 Box 3 ) were shown to be stimulated during $\mathrm{Al}$ stress $[53,54]$. These enzymes are also stimulated during Pi deficiency where malate is known to mobilize external Pi [48]. These two actions are complementary since the chelation of $\mathrm{Al}$ will also free Pi from precipitated Al-phosphate in the rhizosphere. Some of the genes identified in this study may complement the ALMT1 malate transporter to improve Al exclusion. An interesting possibility is that organic acids, such as malate or oxalate, could form intracellular Al-bound complexes that are transported outside the cell (Fig. 3, Box 3). It is possible that the ALMT1 malate transporter (gene \# 84) associated with Al tolerance can transport free malate but that it would require a co-factor to transport the larger Al-bound malate complex. Oxalate is another organic acid known to be a strong $\mathrm{Al}$ chelator associated with $\mathrm{Al}$ tolerance in Taro [55]. This organic acid is another potential molecule that could form an Al complex transported out of the cell by an anion transporter such as ALMT1 or the ABC transporter (gene \# 22) that is up-regulated during $\mathrm{Al}$ exposure. 


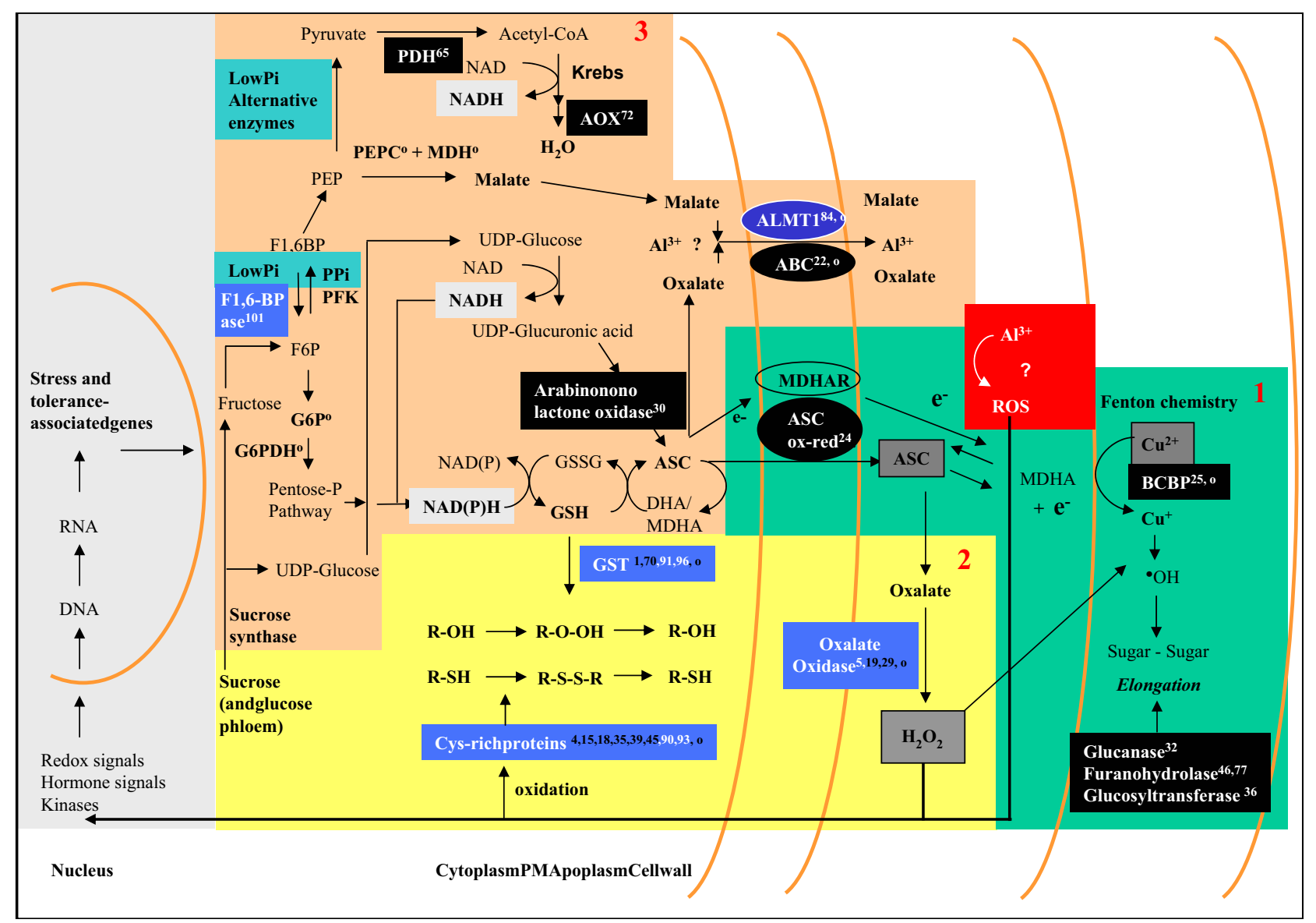

Figure 3

Putative gene function in ascorbate homeostasis and Al tolerance. Al tolerance-associated genes are represented by white numbers* in the dark blue boxes (numbers in black are other genes of the same type associated with Al stress). Genes associated with Al stress responses are in black boxes. Box I) The normal process of cell wall loosening is promoted by the production of hydroxyl radicals $\left({ }^{\circ} \mathrm{OH}\right)$ to break glycosidic linkages (sugar-sugar). The hydroxyl radicals are produced non-enzymatically by the Fenton chemistry in the presence of $\mathrm{Cu}^{2+}, \mathrm{H}_{2} \mathrm{O}_{2}$ and ascorbate which serves as electron donor (the three molecules are in grey boxes). In the apoplasm, ascorbate (ASC) is transformed to monodehydroascorbate (MDHA + e-) and a free electron is used to reduce the $\mathrm{Cu}^{2+}$ to $\mathrm{Cu}^{+}$(needed for the Fenton reaction). An ascorbate oxido-reductase (ASC ox-red), or other plasma membrane transporters may be involved in the regeneration of apoplasmic ASC. Cytoplasmic ASC and NADH are needed to maintain the level of ASC in both compartments. Al (red box) was shown to block a redox reaction (electron transfer) [34] suggesting that it interferes either with the electron transfer from the cytoplasm to ASC (regeneration) or from ascorbate to $\mathrm{Cu}^{2+}$ (utilization). The diverted electron may generate different ROS molecules that will cause oxidative stress and trigger a redox response and the induction of various genes. Box 2) A slower regeneration of ASC could lead to its degradation and to the accumulation of oxalate. The induction of oxalate oxidase can use this oxalate to maintain the production of $\mathrm{H}_{2} \mathrm{O}_{2}$ and support the Fenton reaction. If the apoplasmic ASC concentration decreases too much, $\mathrm{H}_{2} \mathrm{O}_{2}$ may not be used efficiently in the cell wall loosening process and will accumulate. This ROS can cause the oxidation of several targets including different cysteine-rich proteins associated with Al tolerance. GSTs associated with Al stress or tolerance can participate in the protection or repair of oxidized targets. Box 3) Mobilisation of phloem sugars and reduction in phosphate availability (Low $\mathrm{Pi}$ in green) caused by $\mathrm{Al}$ can also participate in gene regulation and stimulate alternative pathways to increase the availability of important metabolite precursors such as NADPH (in light grey) through the pentose-P pathway (G6P: Glucose-6 phosphate; G6PDH: glucose 6 phosphate dehydrogenase); and phosphate (FI,6BP, Fructose I,6 bisphosphatase; PPi PFK: pyrophosphosphate dependent phosphofructokinase). Other alternative pathways are activated to maintain the Krebs cycle (PDH: Pyruvate dehydrogenase, AOX: alternative oxidase) and to stimulate malate production (PEPC: phosphoenol pyruvate carboxylase; $\mathrm{MDH}$ : malate dehydrogenase). UDP-glucose can be used to generate ASC and NADH (arabinonolactone oxidase). Other genes such as ALMTI or ABC transporters may be involved in Al chelation and transport to exclude Al. *: the numbers represent genes identified in this work; see Table I and Table 2. o: genes, enzyme activities or metabolite changes identified in other studies. For references, see text. 
Several proteins encoded by genes that are up-regulated during $\mathrm{Al}$ exposure have a high content of cysteine (Fig. 3, Box 2). The high amount of thiol groups in these proteins may help protect enzymes containing thiol sensitive sites by providing new targets of oxidation. The presence of 11 cysteine residues in the small protein (128 aa) encoded by gene \# 90 may explain why this gene is associated with $\mathrm{Al}$ tolerance (Fig. 3, Box 2). The up-regulation of four different GSTs (genes \# 1, 70, 91, 96), containing cysteine residues in their active sites, indicate that these enzyme may be inactivated by oxidative stress. The synthesis of new enzyme molecules during $\mathrm{Al}$ exposure may partially compensate for GST inactivation. On the other hand, two of the four GSTs are associated with Al tolerance (genes \# 91, 96). These GSTs may help to reduce oxidative stress as suggested for parB, a tobacco GST isoform [25].

\section{Maintenance of root growth}

The ability to maintain root elongation under $\mathrm{Al}$ stress may require complementary mechanisms such as $\mathrm{Al}$ sequestering (outside the cell, or Al exclusion) and increased expression of genes involved in detoxification or root growth. We identified several genes that could play a role in maintaining root growth. Different enzymes such as sugar hydrolases and transferases may participate in cell wall remodelling/loosening in the elongation zone (genes \# 32, 36, 46, 77). During the cell wall loosening process, ascorbate provides an electron to reduce $\mathrm{Cu}^{2+}$ to $\mathrm{Cu}^{+}$(Fig. 3 , Box 1) [56,57], which participates in the Fenton reaction with $\mathrm{H}_{2} \mathrm{O}_{2}$ to ultimately produce $\bullet \mathrm{OH}$ radicals. The non-enzymatic cleavage of cell wall polysaccharides thus requires the presence of three basic molecules: ascorbate, $\mathrm{Cu}^{+2}$ and $\mathrm{H}_{2} \mathrm{O}_{2}$ (grey boxes in Fig. 3) [56,57]. The enzymatic reactions required to maintain/regenerate ascorbate and provide $\mathrm{H}_{2} \mathrm{O}_{2}$ are essential components to maintain root growth and are likely associated with $\mathrm{Al}$ tolerance. The redox activity previously shown to be associated with $\mathrm{Al}$ tolerance [34] may represent the transfer of electrons required to regenerate the apoplasmic ascorbate. The great avidity of $\mathrm{Al}^{3+}$ for electrons (Fig. 3, Box 1) could prevent the regeneration of apoplasmic ascorbate and inhibit root growth. Oxalate oxidase may help maintain the production of $\mathrm{H}_{2} \mathrm{O}_{2}$ for the Fenton reaction (Fig. 3). However, $\mathrm{H}_{2} \mathrm{O}_{2}$ could become a substrate for cell wall peroxidases which are not inhibited when ascorbate levels are reduced [58]. The inhibition of peroxidase activity was associated with $\mathrm{Al}$ tolerance $[59,60]$ and may help maintain $\mathrm{H}_{2} \mathrm{O}_{2}$ levels needed for the non-enzymatic wall loosening process. In our study, three peroxidases (genes \# 13, 21, 58) are up-regulated and could be related to the reduced growth rate under our experimental conditions. Transcripts encoding blue copper binding proteins (BCBP) (gene \# 25) is possibly up-regulated to stimulate the $\mathrm{Cu}^{2+}$ dependent Fenton reaction needed for cell wall loosening. When apoplasmic ascorbate loses an electron, it is transformed into monodehydroascorbate/dehydroascorbate (MDHA/DHA) and new electrons are needed to regener- ate ascorbate and avoid degradation into oxalate (Fig. 3, Box 1). The up-regulation of an ascorbate dependent oxidoreductase (gene \# 24) could be associated with the regeneration of apoplasmic ascorbate (Fig. 3, Box 3). Impaired ascorbate metabolism was proposed to be involved in the reduction of root growth in squash roots exposed to $\mathrm{Al} \mathrm{[38]} \mathrm{while} \mathrm{a} \mathrm{higher} \mathrm{level} \mathrm{of} \mathrm{ascorbate} \mathrm{and}$ gluthathione was shown to be associated with $\mathrm{Al}$ tolerance in tobacco [61]. Furthermore, feeding with D-glucose or L-galactono- $\gamma$-lactone to enhance ascorbate levels was able to improve Al tolerance in rice [62]. These results indicate that maintaining a high ascorbate level is an essential aspect of Al tolerance. Gene \# 30 annotated as an arabinonolactone oxidase is homologous to galactonolactone oxidase involved in ascorbate synthesis (Fig. 3, Box 3 ). This last gene participates in the regeneration of cytoplasmic ascorbate while providing additional NADH (from glucose, Fig. 3, Box 3). The arabinonolactone oxidase is known to synthesize erythroascorbate in yeast. Interestingly, the overexpression of the yeast arabinonolactone oxidase enzyme in rice improves Al tolerance [62].

\section{Conclusion}

Genome wide expression profiling and qRT-PCR using different wheat cultivars subjected to controlled stress treatments allowed the identification of several new genes associated with $\mathrm{Al}$ stress and tolerance. Several genes associated with Al tolerance could play an important role in maintaining the energy balance and $\mathrm{Al}$ exclusion. The maintenance of ascorbate homeostasis is proposed to be a key element to sustain elongation growth. The availability of genes associated with Al tolerance provides new tools for QTL analyses and for breeding programs aimed at improving $\mathrm{Al}$ tolerance of cultivated crops.

\section{Methods}

\section{Plant material, growth and $\mathrm{Al}$ exposure conditions}

Two wheat cultivars with a high tolerance to Al (Triticum aestivum L. cv. Atlas66 and the near isogenic line OK91G106, named Century-T in this work; [32]) and two wheat cultivars with low tolerance to $\mathrm{Al}$ (T. aestivum $\mathrm{L}$. cv. Bounty and the near isogenic line OK91G108, named Century-S in this work; [32]) were grown as previously described, and treated under conditions where $\mathrm{Al}$ remains mostly in the $\mathrm{Al}^{3+}$ form [19]. To reduce $\mathrm{pH}$ variations and ensure that $\mathrm{Al}$ speciation was stable throughout the experiment, at least $100 \mathrm{ml}$ of solution was used for each plant. The root growth inhibition (RGI) is expressed as $100 \times$ [1-(root growth of Al-treated seedling divided by the root growth of control seedlings)]. Replicate experiments were performed on different days with one series of $\mathrm{Al}$ concentration per day per cultivar in order to rapidly collect root tips.

\section{RNA isolation and microarray profiling}

Root tips (5-10 mm) were isolated after 24 hours of exposure to $\mathrm{Al}$ and frozen on dry ice. Total RNA was isolated from the root tips ( $5 \mathrm{~mm}$ long) of 50 plants collected from 
the various genotypes using the RNeasy Plant Mini Kit (Qiagen). The RNA quality was assessed on agarose gels and with the Bioanalyzer 2100 (Agilent). Microarray profiling was performed according to Affymetrix protocols at the Functional Genomics Platform of McGill University and Génome Québec Innovation Centre using the Affymetrix GeneChip ${ }^{\circledR}$ Wheat Genome Array. The microarray results were deposited in the database of ArrayExpress under the accession number E-TABM-454. Three biological replicates of the different lines were treated with $\mathrm{Al}$ concentrations resulting in 50\% RGI: $50 \mu \mathrm{M}$ for the tolerant cultivars Atlas66 and Century-T and $5 \mu \mathrm{M}$ for the sensitive cultivars Bounty and Century-S. The wheat NILs Century-T and Century-S were used only to prepare the Altreated plants due to the limited number of seeds available. In this case, the average value obtained for the untreated (not exposed to $\mathrm{Al}$ ) Atlas66 and Bounty was used as the reference.

\section{Quantitative Real-Time PCR}

The level of expression of selected genes was validated by Real-Time PCR. Probes were designed using the primer3 software and primer specificity was verified on agarose gels and by $\mathrm{T}_{\mathrm{m}}$ measurements at the end of the Real-Time PCR reactions. Total RNA was prepared (RNeasy Plant Mini Kit; Qiagen) from the root tips ( $5 \mathrm{~mm}$ long) of 50 plants collected from the various genotypes and reverse transcribed using SuperScript II reverse transcriptase and random hexamers (SuperSript ${ }^{\mathrm{TM}}$ First-Strand; Invitrogen). Quantitative Real-Time was performed on an ABI 7000 Real Time Cycler using the specific primers described in additional file 3 . One-tenth dilutions of the cDNAs were used as template for the qRT-PCR in a total volume of 25 $\mu \mathrm{L}$ as follows: $12.5 \mu \mathrm{L}$ SYBR Green (Platinum ${ }^{\circledR}$ SYBR $^{\circledR}$ Green qPCR SuperMix-UDG, Invitrogen) $1.0 \mu \mathrm{L}$ primer mix (50:50 mix of forward and reverse primers at 10 $\mathrm{pmol} / \mu \mathrm{L}$ each) and $2 \mu \mathrm{L}$ template. The reaction conditions were: $10 \mathrm{~min}$ at $95^{\circ} \mathrm{C}$ followed by 40 cycles of $1 \mathrm{~min}$ at $95^{\circ} \mathrm{C}$ and $30 \mathrm{~s}$ at $60^{\circ} \mathrm{C}$.

\section{Data analyses}

The microarray data were analyzed using the robust multiarray average (RMA) software (RMA version 0.2 ) of background adjusted, normalized, and log transformed perfect match values [63]. A two-fold cut-off value $\left(\log _{2} \geq 1\right)$ was arbitrarily set to indicate differential gene expression between two samples. Genes showing a differential expression greater than two-fold (RMA differential expression of $\log _{2} \geq 1$ ) between the Atlas 66 and Bounty controls were excluded from the reference set as these may represent inherited cultivar basal expression levels that could bias the analysis. Overall, this excluded $1.26 \%$ of the genes on the microarray (773 of 55,052) demonstrating that most genes are expressed at a similar level between the two cultivars. Genes that are differentially expressed to the same extent in all four cultivars exposed to Al (giving $50 \%$ RGI) compared to the non-treated cultivars were selected and classified as candidates for stress-associated genes. The differentially expressed genes between the two tolerant cultivars exposed to Al (Atlas66 and Century-T) and their respective sensitive counterparts (Bounty and Century-S) exposed to $\mathrm{Al}$ concentrations resulting in 50\% RGI were classified as candidate genes associated with $\mathrm{Al}$ tolerance. These genes were subdivided in two groups (constitutively expressed or Al-regulated) based on the average level of regulation in the two tolerant cultivars. Genes were considered constitutively expressed when the differential signal between Al-treated and non-treated samples was less than two-fold $\left(\log _{2}<1\right)$. An analysis of variance was performed using GraphPad InStat 3 to select genes that are differentially expressed under the conditions specified for each analysis.

For Quantitative Real-Time PCR analyses, the amplification efficiency ( $90 \%$ to $100 \%$ ) for the different primer sets was determined by amplification of cDNA dilution series using $80,20,10,5,2.5$, and $1.25 \mathrm{ng}$ per reaction (data not shown). The variance (standard error) was very small between the PCR replicates for a same biological sample (Real-Time experimental replicate) compared to the variance between the different biological replicates. Calculations and statistical analyses were performed by ANOVA on the mean $\Delta \mathrm{C}_{\mathrm{T}}\left(\mathrm{C}_{\mathrm{T}}\right.$ of each gene $-\mathrm{C}_{\mathrm{T}}$ of 18S RNA used as load control) of different biological replicates, as described in the Results section.

\section{Authors' contributions}

$\mathrm{MH}$ designed the experiment, performed part of the experiments, analyzed the results and prepared the manuscript. AOD performed part of the experiments and their analysis, participated in preparing the figures and critically read the manuscript. All authors have read and approved the final manuscript.

\section{Additional material}

\section{Additional file 1}

Microarray data of candidate stress-associated genes. The differential expression between Al-treated and control (non-treated) samples was analyzed to identify genes that are significantly over-expressed two-fold or more. A first round of selection retained 70 genes for which there is at least two wheat lines with $p$ values $>0.001$ AND $p$ values $>0.01$ in the other two lines. A second round of selection for which there was at least three lines with $p$ values $>0.001$ retained an additional 13 genes (in yellow) for a total of 83 candidate genes. $A=$ Atlas $66 ; B=$ Bounty; $C-T=$ Century$T ; C-S=$ Century-S. Numbers associated with the line's abbreviation $(0$, 5 or 50$)$ represents the Al concentration in $\mu \mathrm{M}$ while the following letter indicates the biological replicate sample number (S1 to S3).

Click here for file

[http://www.biomedcentral.com/content/supplementary/14712164-9-400-S1.xls] 


\section{Additional file 2}

Microarray data of candidate tolerance-associated genes. The differential expression between Al-treated tolerant and sensitive lines (A $50-B 5$ and C-T $50-C-S$ 5) was analyzed to identify genes that are significantly over-expressed two-fold or more in tolerant compared to sensitive lines (ANOVA $p$ values $>0.001$ in one pair AND $p$ values $>0.01$ in the other pair of wheat lines). Genes on this list that were not differentially expressed between Al-treated and the controls (non-treated) are classified as constitutively expressed. $A=$ Atlas66; $B=$ Bounty; $C-T=$ Century- $T ; C$ $S=$ Century-S. Numbers associated with the cultivar's abbreviation $(0,5$ or 50) represents the Al concentration in $\mu \mathrm{M}$ while the following letter indicates the biological replicate sample number (S1 to S3). A: Constitutively expressed candidate genes associated with Al tolerance. B: Up-regulated candidate genes associated with $\mathrm{Al}$ tolerance.

Click here for file

[http://www.biomedcentral.com/content/supplementary/14712164-9-400-S2.xls

\section{Additional file 3}

Primers used for amplification of different transcripts. The transcripts representing the different probesetIDs boxed in Table 1 and Table 2 were used to design unique primers for qRT-PCR.

Click here for file

[http://www.biomedcentral.com/content/supplementary/14712164-9-400-S3.doc]

\section{Acknowledgements}

The authors thank Dr N. Chevrier (UQAM) for bulking up the Atlas 66 seed stock. This work was supported by a Natural Sciences and Engineering Research Council of Canada grant (OGPOI38557) to M.H.

\section{References}

I. von Uexküll HR, Mutert E: Global extent, development and economic impact of acid soils. Plant Soil 1995, I7I:I-I5.

2. Kochian LV, Pineros MA, Hoekenga OA: The physiology, genetics and molecular biology of plant aluminum resistance and toxicity. Plant Soil 2005, 274: I 75- 195.

3. Kochian LV: Cellular mechanisms of aluminum toxicity and resistance in plants. Annu Rev Plant Physiol Plant Mol Biol 1995 46:237-260.

4. Larsen PB, Geisler MJ, Jones CA, Williams KM, Cancel JD: ALS3 encodes a phloem-localized ABC transporter-like protein that is required for aluminum tolerance in Arabidopsis. Plant J 2005, 4 I:353-363.

5. Delhaize E, Ryan PR, Randall PJ: Aluminum tolerance in wheat (Triticum aestivum L.) (II. Aluminum-stimulated excretion of malic acid from root apices). Plant Physiol 1993, 103:695-702.

6. Kidd PS, Llugany M, Poschenrieder C, Gunse B, Barcelo J: The role of root exudates in aluminium resistance and silicon-induced amelioration of aluminium toxicity in three varieties of maize (Zea mays L.). J Exp Bot 200 I, 52: I339-I352.

7. de la Fuente JM, Ramirez-Rodriguez V, Cabrera-Ponce JL, HerreraEstrella L: Aluminum tolerance in transgenic plants by alteration of citrate synthesis. Science 1997, 276: I566-I568.

8. Koyama H, Kawamura A, Kihara T, Hara T, Takita E, Shibata D: Overexpression of mitochondrial citrate synthase in Arabidopsis thaliana improved growth on a phosphorus-limited soil. Plant Cell Physiol 2000, 41:1030-1037.

9. Tesfaye M, Temple S], Allan DL, Vance CP, Samac DA: Overexpression of malate dehydrogenase in transgenic alfalfa enhances organic acid synthesis and confers tolerance to aluminum. Plant Physiol 2001, I 27:1836-1844.

10. Anoop VM, Basu U, McCammon MT, McAlister-Henn L, Taylor GJ: Modulation of citrate metabolism alters aluminum toler ance in yeast and transgenic canola overexpressing a mitochondrial citrate synthase. Plant Physiol 2003, I 32:2205-22 I7.
II. Delhaize E, Ryan PR, Hebb DM, Yamamoto Y, Sasaki T, Matsumoto $\mathrm{H}$ : Engineering high-level aluminum tolerance in barley with the ALMTI gene. Proc Natl Acad Sci U S A 2004, I 0 I : I 5249-I 5254.

12. Magalhaes JV, Liu J, Guimaraes CT, Lana UG, Alves VM, Wang YH, Schaffert RE, Hoekenga OA, Pineros MA, Shaff JE, Klein PE, Carneiro NP, Coelho CM, Trick HN, Kochian LV: A gene in the multidrug and toxic compound extrusion (MATE) family confers aluminum tolerance in sorghum. Nat Genet 2007, 39: I I 56- I I6I

13. Pellet DM, Papernik LA, Kochian LV: Multiple Aluminum-Resistance Mechanisms in Wheat (Roles of Root Apical Phosphate and Malate Exudation). Plant Physiol 1996, I I 2:591-597.

14. Hoekenga OA, Maron LG, Pineros MA, Cancado GM, Shaff J, Kobayashi $Y$, Ryan PR, Dong B, Delhaize E, Sasaki T, Matsumoto H, Yamamoto Y, Koyama H, Kochian LV: AtALMTI, which encodes a malate transporter, is identified as one of several genes critical for aluminum tolerance in Arabidopsis. Proc Natl Acad Sci U S A 2006, I 03:9738-9743.

15. Ishikawa S, Wagatsuma T, Sasaki R, Ofei-Manu P: Comparison of the amount of citric and malic acids in Al media of seven plant species and two cultivars each in five plant species. Soil Sci Plant Nutr 2000, 46:75I-758.

16. Pineros MA, Shaff JE, Manslank HS, Alves VM, Kochian LV: Aluminum resistance in maize cannot be solely explained by root organic acid exudation. A comparative physiological study. Plant Physiol 2005, I 37:231-24I.

17. luchi S, Koyama H, luchi A, Kobayashi Y, Kitabayashi S, Kobayashi Y, Ikka T, Hirayama T, Shinozaki K, Kobayashi M: Zinc finger protein STOPI is critical for proton tolerance in Arabidopsis and coregulates a key gene in aluminum tolerance. Proc Natl Acad Sci U S A 2007, 1 04:9900-9905.

18. Snowden KC, Gardner RC: Five genes induced by aluminum in wheat (Triticum aestivum L.) roots. Plant Physiol 1993, 103:855-861.

19. Hamel F, Breton C, Houde M: Isolation and characterization of wheat aluminum-regulated genes: possible involvement of aluminum as a pathogenesis response elicitor. Planta 1998 , 205:53I-538.

20. Richards KD, Schott EJ, Sharma YK, Davis KR, Gardner RC: Aluminum induces oxidative stress genes in Arabidopsis thaliana. Plant Physiol 1998, I I 6:409-4 I8.

21. Sasaki T, Ezaki B, Matsumoto $H$ : A gene encoding multidrug resistance (MDR)-like protein is induced by aluminum and inhibitors of calcium flux in wheat. Plant Cell Physiol 2002, 43: $177-185$

22. Watt DA: Aluminium-responsive genes in sugarcane: identification and analysis of expression under oxidative stress. J Exp Bot 2003, 54: I 163-1174.

23. Basu U, Good AG, Taylor G]: Transgenic Brassica napus plants overexpressing aluminium-induced mitochondrial manganese superoxide dismutase cDNA are resistant to aluminium. Plant Cell Environ 200I, 24:1269-1278.

24. Ezaki B, Gardner RC, Ezaki Y, Matsumoto H: Expression of aluminum-induced genes in transgenic Arabidopsis plants can ameliorate aluminum stress and/or oxidative stress. Plant Physiol 2000, I 22:657-665.

25. Ezaki B, Katsuhara M, Kawamura M, Matsumoto $H$ : Different mechanisms of four aluminum (Al)-resistant transgenes for $\mathrm{Al}$ toxicity in Arabidopsis. Plant Physiol 2001, I 27:918-927.

26. Ezaki B, Sasaki K, Matsumoto H, Nakashima S: Functions of two genes in aluminium $(\mathrm{Al})$ stress resistance: repression of oxidative damage by the AtBCB gene and promotion of efflux of Al ions by the NtGDII gene. J Exp Bot 2005, 56:266 I-267I.

27. Sivaguru M, Ezaki B, He ZH, Tong H, Osawa H, Baluska F, Volkmann $D$, Matsumoto $\mathrm{H}$ : Aluminum-induced gene expression and protein localization of a cell wall-associated receptor kinase in Arabidopsis. Plant Physiol 2003, I 32:2256-2266

28. Matos M, Camacho MV, Perez-Flores V, Pernaute B, Pinto-Carnide O Benito $C$ : $A$ new aluminum tolerance gene located on rye chromosome arm 7RS. Theor Appl Genet 2005, I I I:360-369.

29. Wight CP, Kibite S, Tinker NA, Molnar SJ: Identification of molecular markers for aluminium tolerance in diploid oat through comparative mapping and QTL analysis. Theor Appl Genet 2006, I | 2:222-231.

30. Berzonsky WA: The genomic inheritance of aluminum tolerance in Atlas-66 wheat. Genome 1992, 35:689-693. 
31. Ma HX, Bai GH, Carver BF, Zhou LL: Molecular mapping of a quantitative trait locus for aluminum tolerance in wheat cultivar Atlas-66. Theor Appl Genet 2005, I I 2:5 I-57.

32. Carver BF, Whitmore WE, Smith EL, Bona L: Registration of four aluminum-tolerant winter wheat germplasms and two susceptible near-isolines. Crop Sci 1993, 33: I | I3- I | |4

33. Sasaki T, Yamamoto Y, Ezaki B, Katsuhara M, Ahn SJ, Ryan PR, Delhaize $E$, Matsumoto $H$ : $A$ wheat gene encoding an aluminumactivated malate transporter. Plant J 2004, 37:645-653.

34. Maltais K, Houde M: A new biochemical marker for aluminium tolerance in plants. Physiol Plant 2002, I I 5:8 I-86.

35. Foyer $\mathrm{CH}$, Noctor $\mathrm{G}$ : Redox homeostasis and antioxidant signaling: a metabolic interface between stress perception and physiological responses. Plant Cell 2005, I7:|866-1875

36. Boscolo PR, Menossi M, Jorge RA: Aluminum-induced oxidative stress in maize. Phytochemistry 2003, 62:181-189.

37. Cakmak I, Horst W J: Effect of aluminium on lipid peroxidation, superoxide dismutase, catalase, and peroxidase activities in root tips of soybean (Glycinemax). Physiol Plant 1991, 83:463-468.

38. Lukaszewski KM, Blevins DG: Root growth inhibition in borondeficient or aluminum-stressed Squash may be a result of impaired ascorbate metabolism. Plant Physiol 1996 , I | 2: I | 35- | | 40

39. Yamamoto Y, Kobayashi Y, Devi SR, Rikiishi S, Matsumoto H: Aluminum toxicity is associated with mitochondrial dysfunction and the production of reactive oxygen species in plant cells. Plant Physiol 2002, I 28:63-72.

40. Takezawa D: Elicitor- and A23 I 87-induced expression of WCK$I$, a gene encoding mitogen-activated protein kinase in wheat. Plant Mol Biol 1999, 40:921-933.

4I. Gorlach J, Volrath S, Knauf-Beiter G, Hengy G, Beckhove U, Kogel KH, Oostendorp M, Staub T, Ward E, Kessmann H, Ryals J: Benzothiadiazole, a novel class of inducers of systemic acquired resistance, activates gene expression and disease resistance in wheat. Plant Cell 1996, 8:629-643.

42. Takezawa $D$ : $A$ rapid induction by elicitors of the mRNA encoding CCD-I, a I4kDa Ca2+ -binding protein in wheat cultured cells. Plant Mol Biol 2000, 42:807-8I7.

43. Arroyo-Serralta GA, Ku-Gonzalez A, Hernandez-Sotomayor SM, Zuniga Aguilar J: Exposure to toxic concentrations of aluminum activates a MAPK-like protein in cell suspension cultures of Coffea arabica. Plant Physiol Biochem 2005, 43:27-35.

44. Vandenabeele S, Van Der KK, Dat J, Gadjev I, Boonefaes T, Morsa S, Rottiers P, Slooten L, Van Montagu M, Zabeau M, Inze D, Van Breusegem F: A comprehensive analysis of hydrogen peroxideinduced gene expression in tobacco. Proc Natl Acad Sci U S A 2003, 100:16113-16118.

45. Gray WM, del Pozo JC, Walker L, Hobbie L, Risseeuw E, Banks T, Crosby WL, Yang M, Ma H, Estelle M: Identification of an SCF ubiquitin-ligase complex required for auxin response in Arabidopsis thaliana. Genes Dev 1999, I3:1678-1691.

46. Quint $M$, Ito $\mathrm{H}$, Zhang W, Gray WM: Characterization of a novel temperature-sensitive allele of the CULI/AXR6 subunit of SCF ubiquitin-ligases. Plant J 2005, 43:37I-383.

47. Jemo $M$, Abaidoo RC, Nolte $C$, Horst WJ: Aluminum resistance of cowpea as affected by phosphorus-deficiency stress. J Plant Physiol 2007, 164:442-45I.

48. Plaxton WC: Plant response to stress: biochemical adaptations to phosphate deficiency. In Encyclopedia of plant and crop science Edited by: Goodman RM. New-York NY USA, Marcel Dekker Inc.; 2004:976-980.

49. Slaski Jj: Differences in the metabolic responses of root tips of wheat and rye to aluminum stress. Plant Soil 1994, I 67: I65-17I.

50. Singh R, Beriault R, Middaugh J, Hamel R, Chenier D, Appanna VD, Kalyuzhnyi S: Aluminum-tolerant Pseudomonas fluorescens: ROS toxicity and enhanced NADPH production. Extremophiles 2005, 9:367-373.

51. Maxwell DP, Wang Y, Mclntosh L: The alternative oxidase lowers mitochondrial reactive oxygen production in plant cells. Proc Natl Acad Sci U S A 1999, 96:827|-8276.

52. Clifton R, Millar AH, Whelan J: Alternative oxidases in Arabidopsis: a comparative analysis of differential expression in the gene family provides new insights into function of non-phosphorylating bypasses. Biochim Biophys Acta 2006, I 757:730-74I.
53. Gaume A, Mächler F, Frossard E: Aluminum resistance in two cultivars of Zea mays L.: Root exudation of organic acids and influence of phosphorus nutrition. Plant Soil 200 I, 234:73-8I.

54. Ermolayev V, Weschke W, Manteuffel R: Comparison of Alinduced gene expression in sensitive and tolerant soybean cultivars. J Exp Bot 2003, 54:2745-2756.

55. Ma Z, Miyasaka SC: Oxalate exudation by taro in response to Al. Plant Physiol 1998, I I 8:86I-865.

56. Liszkay A, van der ZE, Schopfer P: Production of reactive oxygen intermediates $(\mathrm{O}(2)(.-), \mathrm{H}(2) \mathrm{O}(2)$, and (.)OH) by maize roots and their role in wall loosening and elongation growth. Plant Physiol 2004, I 36:3 | |4-3 I 23.

57. Schopfer P: Hydroxyl radical-induced cell-wall loosening in vitro and in vivo: implications for the control of elongation growth. Plant / 200I, 28:679-688.

58. Carmen Cordoba-Pedregosa M, Cordoba F, Villalba JM, GonzalezReyes JA: Zonal changes in ascorbate and hydrogen peroxide contents, peroxidase, and ascorbate-related enzyme activities in onion roots. Plant Physiol 2003, I 3 I:697-706.

59. Cordoba-Pedregosa MC, Villalba JM, Cordoba F, Gonzalez-Reyes JA Changes in intracellular and apoplastic peroxidase activity, ascorbate redox status, and root elongation induced by enhanced ascorbate content in Allium cepa L. J Exp Bot 2005, 56:685-694

60. Souza IRP, Alves VMC, Parentoni SN, Oliveira AC, Teixeira FF, MacAdam JW, Purcino AC: Change in root apical protein and peroxidase activity in response to aluminum in tolerant and sensitive maize inbred lines. Braz J Plant Physiol 2002, I 4:2 19-224.

61. Devi SR, Yamamoto $Y$, Matsumoto $\mathrm{H}$ : An intracellular mechanism of aluminum tolerance associated with high antioxidant status in cultured tobacco cells. J Inorg Biochem 2003, 97:59-68.

62. Guo Z, Tan H, Zhu Z, Lu S, Zhou B: Effect of intermediates on ascorbic acid and oxalate biosynthesis of rice and in relation to its stress resistance. Plant Physiol Biochem 2005, 43:955-962.

63. Irizarry RA, Hobbs B, Collin F, Beazer-Barclay YD, Antonellis KJ, Scherf U, Speed TP: Exploration, normalization, and summaries of high density oligonucleotide array probe level data. Biostatistics 2003, 4:249-264.

64. Richards KD, Snowden KC, Gardner RC: Wali6 and wali7. Genes induced by aluminum in wheat (Triticum aestivum L.) roots. Plant Physiol 1994, I 05: | 455-| 456

65. Delisle G, Champoux M, Houde M: Characterization of oxalate oxidase and cell death in Al-sensitive and tolerant wheat roots. Plant Cell Physiol 200I, 42:324-333.

66. Cruz-Ortega R, Cushman JC, Ownby JD: cDNA clones encoding I,3-beta-glucanase and a fimbrin-like cytoskeletal protein are induced by Al toxicity in wheat roots. Plant Physiol 1997 I | 4: |453-|460.

67. Guo P, Bai G, Carver B, Li R, Bernardo A, Baum M: Transcriptional analysis between two wheat near-isogenic lines contrasting in aluminum tolerance under aluminum stress. Mol Genet Genomics 2007, 277:1-12.

Publish with Biomed Central and every scientist can read your work free of charge

"BioMed Central will be the most significant development for disseminating the results of biomedical research in our lifetime. "

Sir Paul Nurse, Cancer Research UK

Your research papers will be:

- available free of charge to the entire biomedical community

- peer reviewed and published immediately upon acceptance

- cited in PubMed and archived on PubMed Centra

- yours - you keep the copyright 